\title{
Migration and validation of non-formal and informal learning in Europe: Inclusion, exclusion or polarisation in the recognition of skills?
}

\author{
Manuel Souto-Otero ${ }^{1} \cdot$ Ernesto Villalba-Garcia $^{2}$
}

Published online: 17 November 2015

(C) The Author(s) 2015. This article is published with open access at Springerlink.com

\begin{abstract}
This article explores (1) the degree to which immigrants can be considered dominant groups in the area of validation of non-formal and informal learning and are subject to specific validation measures in 33 European countries; (2) whether country clusters can be identified within Europe with regard to the dominance of immigrants in the area of validation; and (3) whether validation systems are likely to lead to the inclusion of immigrants or foster a process of "devaluation" of their skills and competences in their host countries. Based on the European Inventory on validation of non-formal and informal learning project (chiefly its 2014 update) as well as a review of 124 EU-funded (Lifelong Learning Programme and European Social Fund) validation projects, the authors present the following findings: (1) in the majority of European countries, immigrants are not a dominant group in the area of validation. (2) In terms of country clusters, Central European and Nordic countries tend to consider immigrants a dominant target group for validation to a greater extent than Southern and Eastern European countries. (3) Finally, few initiatives aim to ensure that immigrants' skills and competences are not devalued in their host country, and those initiatives which are in place benefit particularly those defined as "highly skilled" individuals, on the basis of their productive potential. There is, thus, a "low road" and a "high road" to validation, leading to a process of polarisation in the recognition of the skills and competences of immigrants.
\end{abstract}

Manuel Souto-Otero

manuelsoutootero@gmail.com

Ernesto Villalba-Garcia

ernesto.villalba-garcia@cedefop.europa.eu

1 School of Social Sciences, Cardiff University, Cardiff, UK

2 European Centre for the Development of Vocational Training (Cedefop), Finikas, Thessaloniki (Pylea), Greece 
Keywords Migrants · Refugees · Validation of non-formal and informal learning · Europe

Résumé Migration et validation de l'apprentissage non formel et informel en Europe : inclusion, exclusion ou polarisation dans la reconnaissance des compétences ? - Le présent article traite trois questions : 1) Dans quelle mesure les immigrants peuvent-ils être considérés comme groupe prédominant pour la validation de l'apprentissage non formel et informel, et font-ils l'objet de mesures spécifiques de validation dans 33 pays européens ? 2) Est-il possible de regrouper les pays européens quant à la prédominance des immigrants dans le domaine de la validation ? 3) Les systèmes de validation sont-ils susceptibles de favoriser l'inclusion des immigrants ou au contraire constituent-ils une « dévaluation » de leurs compétences dans leurs pays d'accueil ? À l'appui de l'Inventaire européen de la validation des acquis non formels et informels (essentiellement sa version de 2014) ainsi que d'un examen de 124 projets de validation financés par l'UE (Programme pour l'éducation et la formation tout au long de la vie et Fonds social européen), les auteurs présentent leurs résultats : 1) Dans la majorité des pays européens, les immigrants ne forment pas un groupe prédominant dans le domaine de la validation. 2) En termes de profils nationaux, les pays scandinaves et d'Europe centrale tendent davantage que les pays d'Europe du Sud et de l'Est à considérer les immigrants comme un groupe cible majeur pour la validation. 3) Quelques initiatives veillent à ce que les compétences des immigrants ne soient pas dévaluées dans leur pays d'accueil, mais les initiatives existantes tirent en premier lieu profit des migrants « hautement qualifiés » en raison de leur potentiel de productivité. Il existe par conséquent une voie "paupérisante » et une voie « royale » vers la validation, qui entraînent une polarisation dans la reconnaissance des compétences des immigrants.

Resumen Migración y validación del aprendizaje no formal e informal en Europa: ¿inclusión, exclusión o polarización en el reconocimiento de competencias y habilidades? - El artículo explora (1) hasta qué punto los inmigrantes pueden ser considerados un grupo dominante en el área de la validación del aprendizaje no formal e informal y disponen de medidas específicas para la validación de sus competencias en 33 países europeos; (2) si es posible identificar grupos de países dentro de Europa que compartan enfoques comunes en relación a la priorización de los inmigrantes en el área de validación; y (3) si los sistemas de validación contribuyen al proceso de inclusión de los inmigrantes o, por el contrario, a un proceso de "devaluación" de sus habilidades y competencias en sus países de acogida. Utilizando información del Inventario Europeo sobre la validación del aprendizaje no formal e informal (principalmente de su edición de 2014), así como una revisión de 124 proyectos en el área de validación financiados por la Unión Europea (por medio de su Programa para el Aprendizaje a lo Largo de la Vida y el Fondo Social Europeo), los autores presentan los siguientes resultados: (1) en la mayor parte de los países Europeos los inmigrantes no son un grupo dominante en las iniciativas sobre validación; (2) en términos de grupos de países, los países del Centro y Norte 
de Europa tienden a considerar a los inmigrantes un grupo dominante en mayor medida que los países del Sur y Este de Europa; y (3) finalmente, hay un número escaso de iniciativas cuyo objetivo sea asegurar que las habilidades y competencias de los inmigrantes no sean devaluadas en su país de acogida; además dichas iniciativas tienden a favorecer particularmente a aquellos individuos que son definidos como "altamente cualificados" con base en su potencial productivo. De este modo existe una "vía lenta" y una "vía rápida" hacia la validación, lo que resulta en un proceso de polarización en el reconocimiento de las habilidades y competencias de los inmigrantes.

\section{Introduction}

\section{Definitions and scope}

Globalisation, mobility and migration are becoming central themes in educational research. As Madeleine Arnot et al. contend,

rethinking the role of education in relation to new movements, flows and networks, and new forms of diversity and identity has become central to educational discourse, in both policy and research (Arnot et al. 2013, p. 567).

But the subject of migration is so sensitive that for a long time, most governments did not include it in their democratic discourse (Baldwin-Edwards 1997). This sensitivity around migration helps to understand why the recognition of formal learning (Xu 2010; Howat et al. 2011) and even more so the validation of nonformal and informal learning have received undeservedly little attention in the literature. In this article, we explore the extent to which immigrants are a dominant user group in the area of validation in European countries, to what extent they are the subject of specific measures and country differences. We also provide some information on the outcomes of validation systems in terms of the inclusion of immigrants, although data in this respect are limited.

"Immigration" is understood here, as in the context of the European Union (EU), as the process by which non-nationals move into a country for the purpose of settlement (IOM 2004, p. 34; see also European Commission 2012). The concept of settlement is important, as it excludes some types of international movement, such as tourism or seasonal work. "Formal learning" takes place in organised and structured environments which are designed for learning - such as schools or higher education institutions; it is based on defined curricula and tends to lead to the award of qualifications recognised in the education system. "Non-formal learning" takes place through planned activities where support for learning is present, for instance workforce development or learning activities organised by civil society organisations. "Informal learning" results from daily activities which are not organised or structured as learning activities and in which learning may be unintentional (Bjørnavold 2000).

While formal learning is made visible through qualifications, non-formal and informal learning (NFIL) is often invisible. Validation is a process which aims to 
make NFIL visible (Bjørnavold 2000) through its identification, documentation, assessment and recognition - socially, in the labour market or in the education system. Validation of NFIL is, as such, different from the recognition of prior learning, which may also include prior learning in formal education. The above definition of "validation" of NFIL is used in this article to enable a comparative analysis, and does not imply that there are no differences in the ways in which validation is defined in European countries (Souto-Otero et al. 2014; Hawley et al. 2010). Validation can take place in relation to knowledge (the outcome of the assimilation of information through learning), skills ${ }^{1}$ (the ability to apply knowledge and use know-how to complete tasks and solve problems) or competences (the proven ability to use knowledge, skills and personal, social and/or methodological abilities, in work or study situations and in professional and personal development) (European Parliament and Council 2008).

Validation of immigrants' NFIL is important for several reasons. Within the study of migration policy and migration regimes we can distinguish two elements: immigrant control policy, which refers to the mechanisms to control admission of foreign citizens, and immigrant policy, which relates to the conditions and rights accorded to immigrants (Hammar 1985). The validation of NFIL can have some bearing on the first aspect, as specific qualification or competence requirements may be imposed for admission into the host country. The recognition of immigrants' knowledge, skills and competences once they have arrived in their host country relates more closely to immigrant policy. In this article, we make reference to both.

Europe is a particularly interesting area for our analysis. Europe's efforts regarding validation compare favourably with those of other world regions (Guo and Shan 2013; Souto-Otero et al. 2008; Souto-Otero 2010). The Council of the European Union's (2012) "Recommendation on the validation of non-formal and informal learning" signalled a new stage of validation in Europe (Villalba-Garcia et al. 2014). It called on EU member states to put validation arrangements in place by 2018

with a view to offering individuals the opportunity to demonstrate what they have learned outside formal education and training - including through mobility experiences (Council of the European Union 2012, p. 3).

The recommendation placed particular emphasis on the importance of validation for disadvantaged groups, as these "are particularly likely to benefit from the validation arrangements, since validation can increase their participation in lifelong learning and their access to the labour market" (ibid., p. 3).

\section{Why study validation for immigrants?}

Validation has consequences for the life chances of immigrants. Two of the main purposes of validation are professional and academic recognition (Souto-Otero 2010). Possessing certain qualifications, education, experience and/or competences which are necessary for the position (s)he is going to fill can be a "condition sine

\footnotetext{
1 While validation can apply to knowledge, skills and competences, we sometimes refer in the text to "skills" to denote those three elements.
} 
qua non" ${ }^{2}$ for labour market-oriented entry for non-EU nationals in some EU member states (European Parliament and International Organization for Migration 2009). This assessment can be based on crude "points systems" which commodify individuals, rather than on sophisticated validation methods, a point we will return to below.

Not only are the stakes of the recognition of the skills and competences different for nationals and immigrants - and indeed for different types of immigrants, such as European and non-European, a point we develop further below - but there are also differences in the process of recognition. The "recognition problem" is particularly acute for immigrants from non-EU (and non-European Economic Area [EEA]) ${ }^{3}$ countries who do not hold educational credentials ${ }^{4}$ from those countries and want to work in regulated professions, as they may need to re-qualify if their qualifications are regarded to be of a lower level than the qualification required in the host country. However, instruments to determine what parts of the qualification are below host-country level or missing are often absent. This is why some governments, like that of the Netherlands, have stimulated measures for the recognition of actual competences of immigrants through a combination of international credential evaluation and validation of NFIL (Scholten 2007). In "de facto recognition" - when there are no legal recognition requirements to practise a profession - immigrants still face the barrier that employers are often unfamiliar with foreign qualifications. The process of recruitment entails checking the level of the foreign qualification against a national qualification, but also ascertaining what the candidate can or cannot do - a validation process.

In some host countries, foreign employees must have

obtained secondary professional education or higher, or possess specific professional qualifications and experience corresponding to the objective requirements for the specific activity to which the work permit relates (European Parliament and International Organization for Migration 2009, p. 175, emphasis added).

Interactive and constructivist approaches which give social aspects a central place in the analysis of cognition and work (Stoof et al. 2000) expose the subjectivity of stakeholders, standards and values in the assessment of competences and, by implication, in validation processes. Competences are defined by stakeholders, who are themselves the product of particular cultures and interactions (Mansfield and Mitchell 1996; see also Prais 2003 for a discussion on national differences in the understanding of mathematical competence). Competence is thus culture- and

\footnotetext{
${ }^{2}$ Latin for an essential/absolutely necessary condition; literally a "condition without which not".

3 While the economic and political European Union (EU) comprises 28 countries (Austria, Belgium, Bulgaria, Croatia, Republic of Cyprus, Czech Republic, Denmark, Estonia, Finland, France, Germany, Greece, Hungary, Ireland, Italy, Latvia, Lithuania, Luxembourg, Malta, the Netherlands, Poland, Portugal, Romania, Slovakia, Slovenia, Spain, Sweden and the UK), the European Economic Area (EEA) extends the EU's single market beyond those 28 countries to include Iceland, Liechtenstein and Norway. Switzerland, which is neither an EU nor an EEA member, is a special case; it is also part of the single European market, including the labour market.

4 In this context, the term "credentials" refers to certified educational qualifications.
} 
context-specific, and these aspects define what competence statements actually mean. Reflecting on one's own competences, a key aspect within the identification phase of validation processes, is a complex undertaking (Scholten 2007). The process of selecting and presenting one's own experience and competences in relation to specific job requirements can be particularly daunting for immigrants. Moreover, in the assessment of NFIL outcomes, assessors are guided by the norms and values of the system within which they operate and its specific conceptions of what is regarded as important. Host-country nationals who have already taken part in the national education system and have social networks which can provide additional information will be more familiar with these aspects than immigrants.

Thus, Jeanine Klaver and Arend Odé (2003) identify the recognition of immigrants' prior learning as one of the main barriers for immigrants' integration. Enabling immigrants to make their own informed judgements about validation systems on equal terms with host-country nationals may require advice and guidance which goes beyond the needs of nationals, and beyond language-related issues. This underlines the need for specifically tailored systems which give immigrants a central place and provide them with target-oriented support.

In the sections below, we review the literature on validation and migration, and describe the methodology we used for the production of our article. This is followed by a presentation of our results and conclusions.

\section{Literature review}

Our literature review proceeds in two stages. First, we discuss consensus and conflict theories as lenses through which to analyse the relationship between immigration and validation, and the notion of regime, with reference to the literature on welfare state and immigration regimes. Second, we explore literature relevant to the extent to which immigrants are a dominant group in the area of validation and to the outcomes of validation systems for immigrants. These two strands of literature have hitherto been largely unconnected. The former body of literature has not given much attention to the role of validation of skills and competences in different migration regimes. The literature on immigration and validation, on the other hand, has tended to be based on individual case studies, and has produced little comparative work to examine the existence of regimes or clusters of countries regarding validation of immigrants' NFIL.

\section{Capitalist states, welfare regimes and immigration}

\section{Labour, capital and immigration}

The two main approaches used by political economists to analyse the relationship between the economy and society are the "consensus" and "conflict" theories. While these approaches do, of course, have multiple ramifications and complexities, it is not our aim here to navigate or resolve these. Rather, we use "stylised" interpretations based on these theories to shed light on the phenomenon of 
recognising immigrants' knowledge, skills and competences. In our current era of migration, consensus theories tend to see skills and migration as inextricably linked: people move with the purpose of finding employment and rewards commensurate with their qualifications and competences (Iredale 2001) while nations fight to attract the most highly skilled individuals in a global "race for talent" (Teitelbaum 2014; Münz 2014; Shachar 2006, European Parliament and International Organization for Migration 2009). Thus, human capital theories see migration as an investment decision, in which expected returns are compared to costs, including risk and uncertainty (Sjastaad 1962). The human capital narrative is that of an even playing field, detached from institutional and national barriers. There is little focus on country differences and groupings. It is the global market which dictates the flows of workers and skills recognition patterns.

Conflict theories assert that the extent to which people who migrate find themselves recognised as skilled workers in their host countries is subject to social struggle and cross-national and temporal variations. According to Marxist analyses, capitalists will support the "import" of immigrants to increase the supply of labour and competition for work and lower wages in order to increase their profits. Immigration also divides the working class through the creation of a "nativeimmigrant" cleavage. Moreover, it creates a "lower class" in the socio-economic ladder, making native workers feel they are higher up, thereby reducing social conflict. In times of economic crisis, immigration can be limited and immigrants expelled for the purpose of preventing recessions from becoming capitalist crises (Castells 1975). In Marxist analyses there are likely to be country variations: in neoliberal countries where employers are more powerful, more lenient migration policies might be expected than in countries where there are strong and well organised labour movements (Meyers 2000).

\section{Immigration regimes}

Following a neo-Marxist class analysis, Gøsta Esping-Andersen (1990) coined the term "welfare regime" to denote how interests, institutions and ideas cluster in particular types of welfare states: liberal (Anglo-Saxon countries, for example), conservative (Central European countries, such as Germany) and social-democratic (such as the Nordic countries). In the social-democratic regime, social protection is highly universalistic in coverage and homogeneous in terms of benefits; the conservative regime is characterised by strong status and group distinctions in the level of benefits, based on occupational background; the liberal regime is characterised by means testing and residualism in welfare provision. Maurizio Ferrera (1996) added a Southern-European model of welfare provision characterised by fragmentation, a low penetration of the State in social welfare sphere and political clientelism.

Diane Sainsbury argues that it is necessary to take into account the special circumstances of immigrants to complement welfare regime typologies with the notion of an immigration regime or an incorporation regime, which takes into account the ways in which immigrants' inclusion in or exclusion from society are regulated. Immigration regimes. 
consist of rules and norms that govern immigrants' possibilities to become a citizen, to acquire residence and work permits, and to participate in economic, cultural and political life (Sainsbury 2006, p. 230).

She examines how welfare regime type, the form of immigration and immigration regimes have shaped immigrants' social rights in the USA (liberal regime and inclusive immigration policy regime); Germany (conservative regime and exclusive immigration policy regime) and Sweden (social-democratic regime and inclusive immigration policy regime) - all of them countries with similar challenges regarding migration.

A number of studies have questioned that "ideal types" of clusters hold when real policies are examined. Christian Joppke (2007) and Joppke and Eva Morawska (2003) have questioned the existence of models because actual migration policies, they argue, combine characteristics of different models, and are characterised by convergence. Regionalisation in Europe leads to the adoption of common approaches. As such, Martin Baldwin-Edwards (1997) refers to a Mediterranean immigration regime which is characterised by poor immigration infrastructure/laws which lead to discrimination against non-nationals, but notes that these are not always implemented in practice due to informal arrangements. He further concludes that more recently international learning and EU membership have brought Mediterranean countries closer to other European countries. Clusters of countries, if they even existed, are being radically transformed, if not disappearing. The literature is thus inconclusive regarding the existence or not of immigration regimes and the results of different approaches to the management of immigration.

\section{Validation in Europe: inclusion and exclusion ${ }^{5}$}

Various analysts (Bjørnavold 2000; Andersson and Guo 2009; Souto-Otero 2010; Diedrich 2013a) have noted that validation is not only a technical process but also a political process, where issues of legitimacy and political struggles are of paramount importance. Social views of immigrants in Europe are rather mixed. While many see immigrants as filling jobs which local people do not want due to their nature or working conditions, many others feel that immigrants take jobs that should be available for local people (European Commission 2011). However, Europeans generally share the feeling that for their country to operate harmoniously, immigrants need to be integrated, and consider language proficiency and employment crucial for integration.

Richard Wanner has argued that non-recognition of foreign qualifications and prior work experience is "the central immigration issue of the new century [...] in all post-industrial societies receiving immigrants" (Wanner 2001, p. 417). This affects both immigrants' employment chances and social integration. In the specific area of validation, there has been scarce albeit valuable research on immigrants in Europe. This has tended to focus on single-country case studies of specific initiatives. The evidence base is stronger in Nordic countries than in the rest of

\footnotetext{
$\overline{5}$ This section relies on Souto-Otero (2016).
} 
Europe. This literature has not concerned itself with the grouping of European countries into clusters, but with the significance of the validation process within countries.

There are two main strands of this body of literature. The first one presents an "inclusive" view of validation, underlining its potential as a tool for social and labour market integration (Jackson 2011). Outside of the EU context, Miri Lerner and Gina Menahem find, based on interviews of over 900 immigrants from the Soviet Union to Israel, that government-led "recredentialization" and retraining were "beneficial in terms of the levels of the occupations achieved by the immigrants" (Lerner and Menahem 2003, p. 23).

A second strand of literature underlines the shortcomings of validation in the real world (Lerner and Menahem 2003; Guo and Andersson 2006; Guo 2010). In this second strand, which presents a "deficit" view of validation, the emphasis is put not on what immigrants may gain in the process of validation, but on what validation processes "miss", resulting in a devaluation of immigrants' prior learning during validation processes. Lerner and Menahem (2003, p. 22) note how "immigrants are subject to formal and informal decredentialization when they are not able to practice in their professions or acquire occupational training in the host society".

Shibao Guo and Per Andersson (2006) and Andreas Diedrich (2013b) document experiences of devaluation of the prior learning of immigrants in Canada and Sweden, which derive from ontological and epistemological misperceptions. Of crucial importance in this process of devaluation is a deficit model of difference, under which the knowledge of immigrants - in particular of those coming from less economically developed countries - is considered inferior and invalid. Skills difficult to map to the host country system are often lumped under an "other" unspecified category. The recognition of knowledge, moreover, is highly racialised and gendered; particular occupations and countries are favoured in most immigration regimes (Williams 2007; Guo and Shan 2013; Le Grand and Szulkin 2002). Under these lenses, validation is seen as a technocratic exercise and a governing tool which presents a barrier to inclusion - it is based on "excluding, normalizing and dividing practices" (Andersson and Guo 2009).

Diedrich (2013a) suggests that many of the validation difficulties immigrants face are due to the focus of validation initiatives on efficiency and on specific occupations. This does not leave room to represent and account for immigrants' full scope of competences and experiences. Governments may also adopt an approach to validation which is too piecemeal, based on fixed-term projects rather than more general frameworks. The results of these projects, Diedrich argues, have generally been disappointing in terms of labour market and social inclusion.

To sum up, the inclusive view of validation focuses on the potential of validation systems which are still evolving and under construction. It compares the situation of immigrants with and without access to validation to conclude that validation is and has the potential to be a positive process. It acknowledges that there are different validation systems, and that not all of them produce the same outcomes in terms of inclusion and social justice (Harris 1999). The deficit view, by contrast, and given its central concern with full inclusion, compares the current situation in validation 
initiatives with a more demanding and idealised scenario, where immigrants' full set of knowledge, skills and competences would be recognised and valued.

The "exclusion" view of validation is a useful counterbalance to what can be an overly enthusiastic view of validation in the "inclusion" literature. But both views run the risk of "essentialising" validation and not sufficiently exploring the connections between validation practices and their social context. Judy Harris (1999) notes that recognition of prior learning has a propensity to reproduce the characteristics of the context of implementation. Validation is a tool, and it is the way in which that tool is used - which is itself conditioned by social views and priorities, regulations and public actions - that will shape it as an inclusionary or exclusionary praxis. France, for example, has a highly developed validation system which is chiefly used by already highly qualified individuals (Duchemin 2014). In Portugal, much emphasis has in recent years been put on the development of validation systems directed at low-qualified citizens (Oliveira Pires 2014). Furthermore, as we propose below, we currently seem to be witnessing a process of exclusion and inclusion - or selective inclusion - of immigrants through validation, rather than simply exclusion or inclusion. This process is based on the polarisation of NFIL validation which divides individuals into two dichotomous classes: the (favoured) "highly skilled" and the others, the "non-highly skilled".

\section{Research questions and methodology}

The empirical part of our article addresses three questions:

(1) Are immigrants dominant user groups in the area of validation in European countries?

(2) What variation and clusters can be found across European countries and why?

(3) What are the outcomes of present systems of validation in terms of the inclusion or exclusion of immigrants in European countries?

In relation to questions 1 and 2, the human capital and globalisation literatures would expect immigrants to be dominant user groups in the area of validation, and few differences among countries as the labour force becomes more mobile and nations increasingly compete for productive labour. From a neo-Marxist standpoint, we would expect greater country differences. In liberal countries, powerful employers would press for validation systems to enable immigrants to work in the host country and identify them as a dominant user group. In Nordic countries, following their universalistic principle in the concession of rights, we would expect to see a high level of recognition of immigrants' skills. In Central-European conservative countries, with strong corporatist associations, recognition would be highly dependent on status and professions. In Southern Europe, due to residualism and the ad-hoc character of social rights except for labour market insiders we would not expect immigrants to be a dominant user group (Ferrera 1996). Regarding the outcomes of validation (question 3), we expect that few specific measures be defined to protect low-skilled immigrants. By contrast, we would expect highskilled immigrants in the "top end" to be particularly protected by the market from 
"devaluation" of their skills in the migration process. This would lead to a polarisation of skills recognition.

The data employed in this study come largely from the European Inventory on validation of non-formal and informal learning project (chiefly its 2014 update; Souto-Otero et al. 2014). It presented information on the state of play in validation in 33 countries (EU Member States, EEA countries, Switzerland and Turkey) as of January 2014. Three reports were produced for the UK (England and Northern Ireland; Scotland; and Wales) and two for Belgium (Flanders and Wallonia), making the total number of reports analysed 36 . We employed two main sets of information from the Inventory: detailed country reports and so-called "country fiches" [tabular overviews]. Both are based on country researchers' in-depth country knowledge of validation practices and frameworks - country reports were structured according to a set of pre-defined headings given to country researchers, and country fiches were constructed based on country researchers' responses to a set of predefined questions. Considerable efforts were made to ensure the accuracy of the information. National descriptions and fiches were circulated to the members of the European Qualifications Framework advisory group and to up to two independent experts. The feedback received showed a high degree of validity and accuracy of the information contained in the national chapters and country fiches.

Country descriptions were analysed using NVivo 9. ${ }^{6}$ A search query of the word "migrant" and synonyms was used. Searches for other relevant words such as "foreign", "immigrant" and "ethnic minority" were also performed. Each of the instances where the words appeared was examined in its context and coded. In addition, while reading the national reports, relevant aspects related to migration were marked and coded.

Country fiches contained standardised information on 27 closed questions (on national validation arrangements, governance, inputs and human resources for validation, focus and results and validation methods). The information we used from the country fiches comes from two questions. The first question (Q23 in the fiche) was: "Which are the dominant user groups of validation opportunities in your country?" Experts could select fifteen options (multiple responses possible) - see Table 1. The answer we employed in the analysis was "migrants/refugees". "Dominant group" was not defined exclusively by quantitative aspects, but also with reference to whether policy or practice tends to take into consideration, at least nominally, certain user groups. Experts provided comments to justify their choices. These comments were used to further refine the categorisation of countries and ensure consistency of interpretation across countries. The second question we used (Q24) was: "What targeted measures are in place?", the responses to which we analysed and coded to document whether specific initiatives for migrants were in place or not by January 2014.

A further source of information we used for this article is a list of EU-funded validation projects generated from the databases of the European lifelong learning programme's electronic platform (Espace Virtuel d'Échange; EVE), and the European Social Fund (ESF). This list of 124 projects gives an indication of the

\footnotetext{
${ }^{6}$ NVivo 9 is a software for qualitative data analysis.
} 
Table 1 Options for dominant user groups

\begin{tabular}{llll}
\hline$\square$ & Males & $\square$ & Jobseekers/unemployed people \\
$\square$ & Females & $\square$ & Individuals at risk of unemployment \\
$\square$ & Young people & $\square$ & Volunteers \\
$\square$ & Low-qualified people & $\square$ & Workers in specific professions/sectors \\
$\square$ & Early school leavers & $\square$ & Experienced and older workers \\
$\square$ & VET* students/applicants & $\square$ & Migrants/refugees \\
$\square$ & HE** students/applicants & $\square$ & Other (please specify groups) \\
$\square$ & Adult learners & & \\
\hline
\end{tabular}

$*$ VET $=$ Vocational Education and Training

$* *$ HE $=$ Higher Education

main topics related to validation funded at European level, in response to nationally generated priorities and demands. The project description was examined and coded in relation to its main target groups and whether they referred to immigrants or not.

It should be noted that we recognise that immigrants are not a uniform group, but a very complex and heterogeneous one, and that there are differences in the entitlements of different immigrant groups (Clayton 2005; Sainsbury 2006). Immigrants who are EU-EEA nationals and those who are not, for instance, are affected differently by validation practices. For example, the EU has issued a recommendation on the validation of non-formal and informal learning to EU countries, and monitors progress against it (Council of the European Union 2012). It has produced supporting tools such as the European Guidelines for validating nonformal and informal learning (Cedefop 2009). These measures are intended to facilitate intra-EU migration. Unfortunately, the data available did not allow us to differentiate systematically between different types of immigrants. While this is a limitation of our research, it should be noted that the distinction between EU and non-EU nationals does not always relate straightforwardly to our research questions. Moreover, while it could be argued that the existence of the above EU measures for EU nationals is likely to make intra-EU immigrants a dominant user group, the existence of those measures does not in fact determine per se whether intra-EU immigrants are considered a dominant user group at the national level. Whether or not this is the case depends on additional factors such as the scope and limitations of those measures, their degree of use/enactment or the existence or absence of national measures which complement them. Country-specific policies and priorities - such as the existence of other groups which are given greater priority with regard to validation and make the attention immigrants (both EU and non-EU) are afforded look comparatively lower - can also help to explain whether migrants/refugees can be considered a dominant user group. Moreover, several issues we discuss in this article - like the importance of cultural and language differences, the situated character of skills and competences and their effects on the results of validation processes - apply to both EU and third-country nationals, although arguably to a different extent. With these caveats in mind, we hasten to note that what we offer here is a first attempt to provide a general analysis which could be further developed for different sub-groups of immigrants in the future. 


\section{Results}

This section presents, first, what we define as the "low road" policies and public systems for immigrants' NFIL validation, which prevails in many European countries with regard to most immigrant groups. Second, it presents some examples of validation initiatives and projects which do aim to take the specificities of immigrants into account. Third, it identifies the emergence of a "high road" for the validation of' NFIL for individuals who are defined as "high-skilled", based on market logics, rather than epistemological, pedagogical or competence-based logic. Finally, it outlines alternative explanations for the prevalence of the "low road".

\section{The low road to validation for immigrants}

Migrants and refugees are not a dominant user group in the area of validation in Europe. Our analysis of a selection of the 124 EU-funded projects from the EVE database reveals that only 6 explicitly mention "migrants" in their abstracts. Thirteen projects were related to the development of validation practices on mobility projects. ${ }^{7}$ While their work in the area of mobility may result in solutions which are relevant to at least some types of immigrants, their primary focus was not on immigrants. At this point, we take a closer look at individual European countries to find out whether there are any discernible differences among them.

Figure 1 shows responses to Question 23 of the 2014 European Inventory country fiche: "Which are the dominant user groups of validation opportunities in your country?" The majority of the countries analysed have validation arrangements in place which target employees in specific sectors of the economy, or applicants to formal or adult education. Immigrants/refugees are, on the other hand, only reported as a dominant user group in $7^{8}$ out of the 24 country fiches for which information on this issue was available. An analysis of the proportion of immigrants in individual European countries (Eurostat 2014a, b) revealed only a weak association between immigration levels and the identification of immigrants/refugees as a dominant user group in the area of validation. Sweden, Ireland and Belgium have relatively high migration levels in the European context, but in Germany, Italy and the Netherlands rates are more modest.

However, the results do suggest a geographical division of countries. Those countries which have immigrants and refugees as a dominant user group in the area of validation tend to be Central European countries (Belgium, Germany, Italy and the Netherlands) or Anglo-Saxon countries (Ireland). By contrast, those countries where immigrants and refugees are not dominant user groups tend to be Southern

\footnotetext{
7 Examples for "mobility projects" are T-TACTIC@SCHOOL - transfer of tools for managing and mentoring the international work placements to recognise competences (http://www.tacticschool.eu/), VILMA - Validation of Informal Learning in Mobility Actions (http://www.vilma-eu.org/) and TRACK Transnational Acknowledgement of Work Experience in Foreign Companies (http://www.trackmobility. eu/track_guidelines.pdf).

${ }^{8}$ Belgium/Flanders, Belgium/Wallonia, Germany, Ireland, Italy, the Netherlands and Sweden.
} 


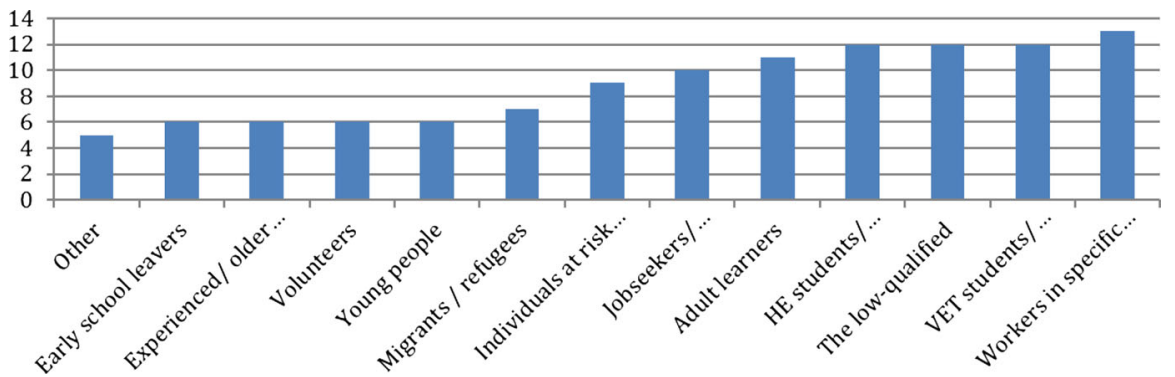

Fig. 1 "Which are the dominant user groups of validation opportunities in your country?" Source European Commission, Cedefop and ICF International (2014), fiche Q23

Table 2 Measures specifically targeting immigrants' needs

\begin{tabular}{ll}
\hline Target measure & Country \\
\hline $\begin{array}{c}\text { Individual projects or target measures } \\
\text { directed at immigrants in place }\end{array}$ & $\begin{array}{c}\text { Austria, Belgium/Flanders, Bulgaria, Switzerland, Germany, } \\
\text { Italy, the Netherlands, Sweden UK/England }\end{array}$ \\
$\begin{array}{c}\text { Individual projects or target measures } \\
\text { directed at other groups in place }\end{array}$ & $\begin{array}{c}\text { Belgium/Wallonia, Denmark, Estonia, Ireland, Iceland, } \\
\text { No specific individual projects or target } \\
\text { measures in place }\end{array}$ \\
Czech Republic, Greece, Spain, Finland, France, Hungary, \\
Liechtenstein, Lithuania, Latvia, Slovak Republic, Turkey
\end{tabular}

Note No information was available for Hungary, Luxembourg, UK/Scotland, UK/Wales

Source European Commission, Cedefop and ICF International 2014, codified answers to Q24, "What targeted measures are in place?"

and Eastern European countries. For Nordic countries the situation is mixed, as they feature more evenly in both groups.

Immigrants might be also part of the other categories, and able to benefit from the robust general validation systems which some European countries have. But, as Table 2 shows, in the majority of countries no particular attention seems to be given specifically to immigrants who, as we have already discussed, have specific needs in the validation process. Only 10 country fiches noted validation projects or targeted measures specifically aimed at immigrants. In Ireland, where immigrants were identified as a dominant user group, no targeted measures were reported; immigrants use the systems available to nationals. But in all other countries where immigrants were defined as a dominant user group, the reports identified specific measures designed for immigrants.

On the whole, our analysis reveals that in the majority of European countries immigrants are on a "low road" to validation, where they are not a dominant user group and there are few measures targeting their needs. 


\section{Country experiences}

This section presents some examples of validation initiatives and projects which do aim to take the specificities of immigrants into account. Seventeen of $35^{9}$ European Inventory (2014 update) reports contain a total of 30 passages referring to "immigrants". This contrasts with 122 instances of appearance, across virtually all reports, of the term "unemployed" as well as numerous references to "low-skilled" individuals - while some immigrants may fall into these categories, many others will not. Moreover, many high-skilled immigrants will still have specific needs which are different from those of host-country nationals. A high proportion of the references to immigrants (12) related to specific projects (which generally address very concrete aspects and are fixed-term) primarily targeting this group, rather than to national policies directed specifically at immigrants (see also Diedrich 2013a; Guo and Andersson 2006).

The material shows that in some cases immigrants do receive specific support during validation processes. For example, in Austria, the Ministry of the Interior and Ministry of Labour Social Affairs and Consumer Protection launched an information initiative in 2012 for professional recognition [Berufsanerkennung] targeting immigrants. A website ${ }^{10}$ provides information about the acceptance and recognition of vocational qualifications or professional experience acquired in other countries, and counselling is offered at dedicated information centres. There are other project initiatives which target low-qualified individuals, with a focus on immigrants. An example of this is the "You have skills [Du kannst was!!]" initiative, also in Austria, a pilot project in two provinces directed at individuals, in particular immigrants, with a low level of qualifications. ${ }^{11}$ Participants can obtain certificates if they are successful in the final apprenticeship examination. Counselling for immigrants is also in place, informing potential validation participants about the opportunities for and requirements of participation. If they decide to participate, personal portfolios are created with a focus on competences relevant for the individual's chosen profession.

Measures taking the specificity of immigrants into account can also be in place at the time of assessment. In some Nordic countries, the candidate's cultural and linguistic background is taken into consideration when planning validation tests. But this tends not to be the case in countries where validation is more summative in nature and less integrated in the guidance process. In Sweden, recent validation initiatives have aimed to make validation a central part of the initial integration activities for immigrants to shorten the time it takes for them to make the transition to the labour market. The validation process varies according to the goals and background of the individual, but encompasses a "competence mapping" phase which involves information and identification of competences, and a second stage of "competence assessment" which tests individuals on their knowledge, skills and competences against specific standards. In Belgium/Wallonia, validation of

\footnotetext{
9 The country report for Switzerland could not be included in the analysis.

${ }^{10}$ See http://www.bmeia.gv.at/en/integration/recognition-of-qualifications/ [accessed 5 October 2015]. This website includes an English language option.

${ }^{11}$ See http://www.dukannstwas.at/ [accessed 5 October 2015]. This website is only available in German.
} 
competences (Validation des Compétences; VDC) is carried out by continuous vocational training centres. VDC leads to the award of a skills certificate [Titre de Compétence]. Skills certificates can be accumulated to obtain a qualification in the adult education sector, after having passed an integrated final test [épreuve intégrée]. In this system, targeted efforts are dedicated to engaging groups which are particularly hard to reach, especially immigrants. This is done through cooperation with organisations working directly with these groups, such as regional centres dedicated to supporting and integrating immigrants. However, this system creates "A" and "B" certificate types, and has been under revision since 2014.

The assessment phase in a large set of countries is closely linked to formal education and does not provide much scope for intercultural dialogue and exchange. For example, in Germany, the Vocational Qualifications Assessment Law (Berufsqualifikationsfeststellungsgesetz; BQFG) (FRG 2012) introduced the right to match foreign qualifications to formal German qualifications. The law (ibid., para 3, "Introduction" section) also permits the validation of appropriate work experience towards acquired formal qualifications. In Germany, the main method used for validation is external exams, in which all individuals (those seeking NFIL validation and those who have taken formal education courses) sit the same exam. This is done to assure the quality of the outcomes, reduce the costs of tests and give equal status to the qualifications acquired through validation - a system which is also common in several other European countries. However, immigrants are clearly likely to face specific challenges in relation to this type of validation practice.

There are, therefore, a number of pilot initiatives and projects in place at different stages of validation (identification, documentation, assessment and recognition) in European countries. While those reviewed above are valuable initiatives, their reliance on project-based work raises questions regarding sustainability after the project life has ended, as well as issues around lack of linkage with parts of the education system (e.g. to follow up validation with further training) which may be beyond the scope of the project. In addition, many initiatives are linked to formal qualifications and they consider competences acquired through NFIL not linked to national formal qualifications more marginally.

\section{The high road to validation for immigrants}

Validation systems are portrayed to work for the inclusion of all types of immigrants. However, systems can be set up which cater particularly for those immigrants who have a potentially stronger link with the labour market: highly skilled immigrants and those whose skills match labour market demands. Validation systems can lead to the "disappearance" of the skills and competences possessed by individuals defined as non-highly skilled: while those defined as high-skilled find it easier to get their competences recognised by employers and governments, those outside that category see themselves encumbered with difficulties and pushed towards the bottom. This leads to a polarisation in the recognition of knowledge, skills and competences between the "high-skilled" and the "non-high skilled". 
EU countries do not see immigrants as a uniform category, and not all immigrants are treated equally. Henk van Houtum and Roos Pijpers (2007) note that in the EU there has been a tightening in immigrant control policy to favour those who can be of economic value in host countries. Rather than inclusion or exclusion, validation systems may selectively recognise the skills of some migrants and not those of others. Those working in shortage sectors or in particular those considered to be at the high end of the productive spectrum and key to economic competitiveness are favoured - and these will vary by country. Meanwhile, the skills and competences of those working at the middle and low added value end of the market - in those jobs which improve products or services and the difference between costs and retail price only marginally - and outside key sectors, or who do not already have an employment offer are treated unfavourably due to the lack of suitable systems for the validation of their NFIL.

This process can be most clearly illustrated with reference to immigration control policy for third-country nationals, and their right to reside and work in the host country. While regulations differ among EU countries, and immigration policies in the EU do not respond exclusively to labour market considerations, in an increasing number of European countries, the admission of third-country nationals depends on their performance in a "points system" or a similar scheme which takes into account a set of criteria to define some individuals as "high-skilled". The European Parliament and International Organization for Migration (2009) name six countries from very diverse political economies and welfare regimes as having special schemes for high-skilled workers: the Czech Republic, Denmark, France, Ireland, the Netherlands and the UK; others offer favourable conditions such as Germany or Belgium. Their points systems often take into account prior educational qualifications and salary - to which other criteria such as an existing link to the host country and age can be added. In Belgium, those who have completed tertiary education can obtain a work permit for at least four years if their salary is going to be higher than EUR 33,082 per year; to obtain a Green Card in Ireland, an applicant requires a job offer which has an annual salary above EUR 60,000, or above EUR 30,000 in a strategically important field such as IT, healthcare, construction or financial services (European Parliament and International Organization for Migration 2009). In the Netherlands, the highly skilled migrants scheme (which again is presented as being skills-related, but is actually largely based on future income) requires earnings above EUR 4,189 per month excluding holiday allowance for those aged over 30, and EUR 3,071 for those under 30 (Dutch Ministry of Security and Justice 2015). Minimum income requirements are also set for non-highly skilled migrants, but these do not benefit from the advantages of highly skilled migrant schemes.

Those defined as highly skilled immigrants based on the salary offered by their prospective employers are eligible for specific programmes which afford them more lenient, straightforward or faster approval procedures for entry (European Parliament and International Organization for Migration 2009). So admission is based on a set of criteria which identify competence with reference to formal education and the "market value" of the skills and competences developed through formal and non-formal/informal learning. Salary becomes a reductionist assessment criterion to make competences visible and select "high-skilled" individuals from amongst those 
who hold the minimum formal education credentials (often a higher education qualification) required in the host country. Skill is defined as the capacity to contribute to national economic success and generate direct revenue (create wealth) for the host country.

Some parts of validation systems thus operate - at least in some countries - under market logics through the decision-making of employers, with little intervention of public validation systems, except to sanction the decision of the private sector and provide certain entitlements to highly skilled immigrants. In the cases reviewed in this subsection, employers have a key role in deciding what the skills of the individual are and whether he/she wants to support admission into the country, including through the offer of a sufficiently high salary.

\section{Explaining the "low road"}

The lack of more inclusive general systems of validation which put immigrants at the centre (the existence of a "low road" to validation) can be explained in various ways. First, validation systems might face practical constraints. There can be economic reasons for the "devaluing" - or "decredentializing" (Lerner and Menahem 2003) - nature of validation for immigrants, because it is not possible to identify and recognise their full set of competences in the absence of sufficient expertise, time and resources. This is not to deny that the devaluation process can be made more prominent due to procedural and managerial biases towards certain outcomes (Guo 2010).

Second, immigrants are likely to be negatively affected by the situated character of skills and competences. Skills, competences and qualifications suffer a "break in journey" in the process of migration: not all skills and competences which can be used in the home country will be equally useful in the host country - the example of a labour lawyer provides clear evidence of that - and those which cannot be used tend to be excluded from validation in the host country. Ann-Zofie Duvander (2001) finds that the pay gap between immigrants and native-born Swedish employees is partly, although not fully, explained by immigrants' lack of "country-specific skills". This recognises that learning and skills are socially situated, and that "migrants have to acquire place-specific knowledge if they are to valorise fully other forms of knowledge" (Williams 2007, p. 4).

But validation also can be used as a tool for exclusion: the artificial "construction" of differences in competences between home and host country, over and above the above-mentioned "break in journey" or discontinuity, can be employed as a mechanism to protect host-country national workers against competition from immigrants (Williams 2007). The use of limits in the validation of immigrants' knowledge, skills and competences may provide a more palatable medium for discrimination than other types of labour market discrimination. Validation thus can be used to conceal intolerance for diversity (Duvander 2001). It can also act as a "directive" device for immigrants, devaluing the recognition of their competences so that they do not seek jobs at their real competence levels, as these are likely to be given to nationals, and focus on the jobs that nationals do not 
want. There is some evidence that labour market discrimination also occurs when immigrants acquire qualifications in their host country (Bonikowska et al. 2011). Inclusive validation, under this interpretation, would raise expectations for immigrants, only to then subject them to facing discrimination in the labour market.

\section{Conclusions}

In this article we have addressed three questions regarding the validation of immigrants' NFIL in Europe, based on country-level data from a comparative study encompassing 33 European countries. Our first question referred to the extent to which immigrants are a dominant user group of validation initiatives, and are the subject of specific validation initiatives or policies. Our results suggest that in the majority of EU countries, immigrants are not a dominant user group in the area of validation. Other groups, such as unemployed or young people are more dominant, and while some initiatives targeting immigrants do exist, these tend to be project-based and short-term, rather than long-term policies. These findings corroborate and extend the results of previous national research (e.g. Diedrich 2013a) to a broader set of countries.

Regarding the second question, we found a geographical division of countries, with Central European, Anglo-Saxon and some Nordic countries considering immigrants a dominant user group to a greater extent than Southern and Eastern European countries. While this finding requires further investigation, it would seem to contradict the predictions which we derived from critical theory, as it is in those countries where labour movements have traditionally had greater weight that immigrants are reported to be given greater prominence in the area of validation of NFIL. This may have something to do with the fact that labour markets are also more regulated in Central European and Nordic countries than in Southern and Eastern European countries. Moreover, and as already mentioned, in most countries initiatives are based on fixedterm project work rather than more stable policies. In terms of actual policies and approaches, it is thus challenging to see the emergence of clear and distinctive regimes in the area of validation. What is apparent is that Europe is far from the institutionally free "level playing field" implied by human capital theory.

Finally, regarding the outcomes of validation in practice, our analysis did not reveal a wealth of public sector initiatives specifically targeting immigrants and low-skilled immigrants. This finding leads to a concern that such validation mainly takes place in the market, which tends to favour high-skilled individuals. While immigrants with low skills levels have been shown to experience devaluation in the recognition of their skills, at the "high end" there is a degree of "emergent" interjurisdistictional competition which at least some European countries have entered to attract immigrants who can contribute to the high-added value segments of the economy. Policy-makers in those aspiring "magnet" destinations try to surpass the efforts of their international competitors to attract skilled immigrants, exchanging "talent for citizenship" (Shachar 2006). This would support the hypothesis of polarisation, or inclusion of certain immigrants and exclusion and devaluation of others, rather than support a simple narrative of inclusion or exclusion. 
The present article has provided some indications and trends which need to be further explored and tested in the future. There is, generally, a dearth of data on validation, and more data pertaining to - specifically - validation and immigration need to be collected. In particular, it will be important that future analyses are able to differentiate between types of/reasons for immigration and their relationship to specific validation practices.

Open Access This article is distributed under the terms of the Creative Commons Attribution 4.0 International License (http://creativecommons.org/licenses/by/4.0/), which permits unrestricted use, distribution, and reproduction in any medium, provided you give appropriate credit to the original author(s) and the source, provide a link to the Creative Commons license, and indicate if changes were made.

\section{References}

Andersson, P., \& Guo, S. (2009). Governing through non/recognition: The missing "R" in the PLAR for immigrant professionals in Canada and Sweden. International Journal of Lifelong Education, 28(4), 423-437.

Arnot, M., Schneider, C., \& Welply, O. (2013). Education, mobilities and migration: People, ideas and resources. Compare: A Journal of Comparative and International Education, 43(5), 567-579.

Baldwin-Edwards, M. (1997). The emerging European immigration regime: Some reflections on implications for Southern Europe. Journal of Common Market Studies, 35(4), 497-519.

Bjørnavold, J. (2000). Making learning visible. Luxemburg: Cedefop.

Bonikowska, A., Hou, F., \& Picot, G. (2011). A Canada-US comparison of labour market outcomes among highly educated immigrants. Canadian Public Policy, 37(1), 25-48.

Castells, M. (1975). Immigrant workers and class struggles in advanced capitalism: The Western European experience. Politics and Society, 5(1), 33-66.

Cedefop (European Centre for the Development of Vocational Training) (2009). European guidelines for validating non-formal and informal learning. Luxembourg: Office for Official Publications of the European Communities.

Clayton, P. (2005). Blank slates or hidden treasure? Assessing and building on the experiential learning of migrant and refugee women in European countries. International Journal of Lifelong Education, 24(3), 227-242.

Council of the European Union (2012). Council Recommendation of 20 December 2012 on the validation of non-formal and informal learning. Resolutions, recommendations and opinions 2012/C 398/01. Official Journal of the European Union. Brussels: Council of the European Union. Accessed 1 October 2015, from http://eur-lex.europa.eu/legal-content/EN/TXT/PDF/?uri=CELEX:32012H1222 (01)\&from $=\mathrm{EN}$.

Diedrich, A. (2013a). Translating validation of prior learning in practice. International Journal of Lifelong Education, 32(4), 548-570.

Diedrich, A. (2013b). Who's giving us the answers? Interpreters and the validation of prior foreign learning. International Journal of Lifelong Education, 32(2), 230-246.

Duchemin, C. (2014). European Inventory on validation of non-formal and informal learning 2014: Country report France. Luxembourg/Thessaloniki/Fairfax, VA: European Commission; Cedefop; ICF International. Accessed 1 October 2015, from http://libserver.cedefop.europa.eu/vetelib/2014/ 87058_FR.pdf.

Dutch Ministry of Security and Justice (2015). Income requirements. Almelo: Dutch Ministry of Security and Justice, Immigration and naturalisation service (IND). Accessed 10 January 2015, from https:// ind.nl/en/individuals/employee/costs-income-requirements/Income-requirements.

Duvander, A. Z. E. (2001). Do country-specific skills lead to improved labor market positions? An analysis of unemployment and labor market returns to education among immigrants in Sweden. Work and Occupations, 28(2), 210-233.

Esping-Andersen, G. (1990). The three worlds of welfare capitalism. Cambridge: Polity Press. 
European Commission (2011). Migrant integration: Qualitative Eurobarometer. Luxembourg: Office for Official Publications of the European Communities.

European Commission (2012). Online glossary. European immigration portal. Accessed 2 February 2015, from http://ec.europa.eu/immigration/glossary_en.

European Commission, Cedefop \& ICF International (2014). 2014 update of the European Inventory on validation of non-formal and informal learning. Final project report. Brussels: ICF International.

European Parliament and Council (2008). Glossary of the Recommendation of the European Parliament and of the Council of 23 April 2008 on the establishment of the European Qualifications Framework for Lifelong Learning. Official Journal of the European Union. C 111, 6.5.2008. Accessed 5 October 2015, from http://www.eucen.eu/EQFpro/GeneralDocs/FilesFeb09/GLOSSARY.pdf.

European Parliament \& International Organization for Migration (2009). Laws for legal immigration in the 27 EU member states: International migration law $N^{\circ} 16$. Geneva: International Organization for Migration.

Eurostat (2014a). Immigration by five year age group, sex and citizenship (online code migr_imm1ctz). Luxembourg: European Commission. Accessed 5 October 2015, from http://appsso.eurostat.ec. europa.eu/nui/show.do.

Eurostat (2014b). Population on 1 January by five year age group, sex and citizenship (online code migr_pop1ctz). Luxembourg: European Commission. Accessed 5 October 2015, from http://appsso. eurostat.ec.europa.eu/nui/show.do.

Ferrera, M. (1996). The "Southern model" of welfare in social Europe. Journal of European social policy, 6(1), 17-37.

FRG (Federal Republic of Germany) (2012). Gesetz über die Feststellung der Gleichwertigkeit von Berufsqualifikationen (Berufsqualifikationsfeststellungsgesetz - BQFG [Vocational Qualifications Assessment Law]). Berlin: Government of the Federal Republic of Germany. Accessed 5 October 2015, from http://www.gesetze-im-internet.de/bundesrecht/bqfg/gesamt.pdf.

Guo, S. (2010). Toward recognitive justice: Emerging trends and challenges in transnational migration and lifelong learning. International Journal of Lifelong Education, 29(2), 149-167.

Guo, S., \& Andersson, P. (2006). Non/recognition of foreign credentials for immigrant professionals in Canada and Sweden: A comparative analysis. Edmonton: Prairie Centre of Excellence for Research on Immigration and Integration.

Guo, S., \& Shan, H. (2013). The politics of recognition: Critical discourse analysis of recent PLAR policies for immigrant professionals in Canada. International Journal of Lifelong Education, 32(4), 464-480.

Hammar, T. (Ed.). (1985). European immigration policy: A comparative study. Cambridge: Cambridge University Press.

Harris, J. (1999). Ways of seeing the recognition of prior learning (RPL): What contribution can such practices make to social inclusion? Studies in the Education of Adults, 31(2), 124-139.

Hawley, J., Souto-Otero, M. \& Duchemin, C. (2010). 2010 update of the European Inventory on validation of non-formal and informal learning: Final report. Brussels: GHK Consulting. Accessed 1 October 2014, from http://edz.bib.uni-mannheim.de/daten/edz-b/gdbk/10/Europ_Invent_Valid_ final.pdf.

Howat, C., Ulicna, D. \& Harris, P. (2011). Study evaluating the professional qualifications directive against recent educational reforms in EU Member States: Revised final report to DG Internal Market and Services. London: GHK Consulting, in association with Danish Technological Institute (DTI). Accessed 1 October 2014, from http://ec.europa.eu/internal_market/qualifications/docs/ policy_developments/final_report_en.pdf.

IOM (International Organization for Migration) (2004). Glossary on migration. Geneva: IOM.

Iredale, R. (2001). The migration of professionals: Theories and typologies. International Migration, 26(1), 7-26.

Jackson, S. (2011). Lifelong learning and social justice. International Journal of Lifelong Education, 30(4), 431-436.

Joppke, C. (2007). Beyond national models: Civic integration policies for immigrants in Western Europe. Western European Politics, 30(1), 1-22.

Joppke, C., \& Morawska, E. (Eds.). (2003). Towards assimilation and citizenship. Houndmills: Palgrave Macmillan.

Klaver, J., \& Odé, A. (2003). De arbeidsintegratie van vluchtelingen: Een verkenning van problemen en oplossingen [Labour market integration for refugees: An exploration of problems and solutions]. The Hague: Raad voor Werk en Inkomen. 
Le Grand, C., \& Szulkin, R. (2002). Permanent disadvantage or gradual integration: Explaining the immigrant-native earnings gap in Sweden. Labour, 16(1), 37-64.

Lerner, M., \& Menahem, G. (2003). Decredentialization and recredentialization: The role of governmental intervention in enhancing occupational status of Russian immigrants in Israel in the 1990s. Work and occupations, 30(1), 3-29.

Mansfield, B., \& Mitchell, L. (1996). Towards a competent workforce. Aldershot/Brookfield: Gower.

Meyers, E. (2000). Theories of international immigration policy: A comparative analysis. International Migration Review, 34(4), 1245-1282.

Münz, R. (2014). The global race for talent: Europe's immigration challenge. Bruegel Policy Brief, issue, 2014(2), 1-8.

Oliveira Pires, A.L. (2014). European Inventory on validation of non-formal and informal learning 2014: Country report Portugal. Accessed 5 October 2015, from https://cumulus.cedefop.europa.eu/files/ vetelib/2014/87073_PT.pdf.

Prais, S. J. (2003). Cautions on OECD's recent educational survey (PISA). Oxford Review of Education, 29(2), 139-163.

Sainsbury, D. (2006). Immigrants' social rights in comparative perspective: Welfare regimes, forms in immigration and immigration policy regimes. Journal of European Social Policy, 16(3), 229-244.

Scholten, A. M. (2007). Exploration of portfolio characteristics for the recognition of prior learning: the identification, assessment and recognition of actual competencies of highly-skilled immigrants. Twente: University of Twente.

Shachar, A. (2006). The race for talent: Highly skilled immigrants and competitive immigration regimes. New York University Law Review, 81(148), 149-206.

Sjastaad, L. A. (1962). The costs and returns of human migration. Journal of Political Economy, 70(5), 80-93.

Souto-Otero, M. (2010). Validation of non-formal and informal learning in Europe: Between vocationalism and social change. In G. Elliot, C. Fourali, \& S. Issler (Eds.), Education and social change (pp. 251-263). London: Continuum Books.

Souto-Otero, M. (2016). Validation of non-formal and informal learning in Europe: Research, policies, legitimacy and survival. In S. Bohlinger, G. Klatt \& K.A. Dang (Eds), Education policy. Frankfurt/ Main: Peter Lang.

Souto-Otero, M., Fleckenstein, T., \& Dacombe, R. (2008). Filling in the gaps: European governance, the open method of coordination and the European Commission. Journal of Education Policy, 23(3), 231-249.

Souto-Otero, M., Murphy, I., Duchemin, C., Hawley, J., Alvarez-Bermúdez, N. \& Coles, M. (2014). European Inventory on validation of non-formal and informal learning. 2014. Final synthesis report. Thessaloniki: Cedefop. Accessed 2 February 2015, from http://libserver.cedefop.europa.eu/ vetelib/2014/87244.pdf.

Stoof, A., Martens, R. L., \& Van Merriërenboer, J. J. G. (2000). What is competence? A constructivist approach as a way out of confusion. Paper presented in May at the Onderwijs Research Dagen (ORD) in Leiden.

Teitelbaum, M. (2014). Falling behind: Boom, bust and the global race for scientific talent. Princeton, NJ: Princeton University Press.

Van Houtum, H., \& Pijpers, R. (2007). The European Union as a gated community: The two-faced border and immigration regime of the EU. Antipode, 39(2), 291-309.

Villalba-Garcia, E., Souto-Otero, M., \& Murphy, I. (2014). The 2014 European Inventory on validation of non-formal and informal learning: Prospects and trends of validation in Europe. BWP, 5(2014), 16-19.

Wanner, R. A. (2001). Diagnosing and preventing "brain waste" in Canada's immigrant population: A synthesis of comments on Reitz. Journal of International Migration and Integration, 2(3), 417-428.

Williams, A. M. (2007). International labour migration and tacit knowledge transactions: A multi-level perspective. Global Networks, 7(1), 29-50.

$\mathrm{Xu}, \mathrm{Y}$. (2010). Is transition of internationally educated nurses a regulatory issue? Policy, Politics and Nursing Practice, 11(1), 62-70. 


\section{The authors}

Manuel Souto-Otero is Senior Lecturer in Social Sciences (Education Policy) at the School of Social Sciences, Cardiff University, UK. His main areas of work are non-formal and informal learning, the link between education and work, internationalisation in education.. He holds a doctorate in Social Policy from the University of Oxford.

Ernesto Villalba-Garcia works as an Expert at the European Centre for the Development of Vocational Training (Cedefop) in Thessaloniki, Greece. He previously worked at the Centre for Research in Lifelong Learning of the European Commission Joint Research Centre. He holds a Ph.D. in Comparative and International Education from Stockholm University. 